\title{
Motivation to Defend Restrictively Love of Jan Van Loos in Tulip Fever Film by Justin Chadwick
}

\author{
Muji Endah Palupi \\ English Department \\ Akademi Bahasa Asing BSI Jakarta \\ Jl. Salemba Tengah No. 45 Paseban, Jakarta Pusat \\ muji.mji@bsi.ac.id
}

\begin{abstract}
In fiction represents the life of people explicitly. The characters on the film represent of life in the real world. In Tulip Fever the work of Justin Chadwick is telling the story in Holland in the seventieth century. In which, Tulip is becoming the star of a flower which looked for by all people. On the other hand, there is an artist or painter that falls in love with the wife of patrician; he believes that it could be defended forever. The aim of this study is to comprehend the motivation of the main character, Jan Van Loos to make and defend his restricted love to Sophia, the wife of a Holland patrician, Cornelis Sandvoort. This research is using a qualitative descriptive method, in which the writer analyzes the movie scene by scene. The result of this research is expected to be used for next researcher to analyze the motivation to make and defend restricted love of the main character, or other objects.
\end{abstract}

Keywords: Film, Tulip Fever, Restricted Love

\section{INTRODUCTION}

God creates human to spread love among them. They get in touch each other to know themselves. The interaction evokes affection among them. As we know, that God has only created man and woman, they are fated to be a couple in this world. Like God created Eve to company Adam in heaven, even she had misled him into wrong path to eat "apple". Since that happen, Adam had to get his punishment to be driven away from heaven. A woman sometimes could be partner. Hence, she could be also a foo in life. Faithfully, a man must believe that 'a good woman for a good man'. It is only the time that could determine it. As long he wants to be patient in a waiting time. God has determined humans' partners.

So, what type of woman that could be selected by a single man? Surely, the woman has a good attitude and also her face. Indeed, this thing could not be avoided by every single man. We should know that, pretty face is not everything for a woman. It shloud be balanced with her attitude. So, the pretty face is not a number one, also the wealth of her, but the manner or attitude that would be added value to all women. Especially, for a man who is faithful to build his new family. In which, the woman would be a mother of his children. She will become the first school for them, and to be last shelter until the end of his life.

We could see on $U p$ animation movie that made by Disney featuring Pixar. The story of a seventy-eight year old man, namely Carl, he was ambitious to provide his wife's dream to go advanture to Paradise Fall, until he met a fat scout boy, Russel. Talking about Carl's wife, Elly, she had a romantic life story with Carl. They met when they were children, until they were growing up and decided to get married. Their life was not smooth as they thought. They had to meet any life obstacles. But they were strong, one day Elly was pregnant, but God had another aim for them. Elly was so sad, but Carl could calm her down. He gave her spririt to spend her life to go adventure to Paradise Falls. But, time by time, Elly could not achive her dream. She left this world early. The romantic session had gone forever, except Carl.

Love could come from every single sides. It could not be geussed by human. It could be desired from eyes then falls to human's heart. Love could be found in every human's heart. When a man has already found his love, as if the world is owned by him. He fills it with his over, and builds a kingdom of love in it. Sometimes love could hurt human. It happened to an Indonesian folk tale. A story of Syamsul Bahri, a Minangkabau man of West Sumatra. He fell love to Siti Nurbaya. It was his first love. He promised to marry her, it is just waiting the time. But, time goes by early, the parents of Siti Nurbaya had a big debt to Datuk Maranggih, the old, rich, and arogan man. He had everything in the land of Minang. He told to Siti's parent, that she was the hostage of debt. He wanted her to be his wife. Her parent could refuse of Datuk's desire. They let Siti to be taken by Datuk. Syamsul could not do anything, he also let Siti being taken by Datuk. His love was crashed, his heart has broken until he died, and nothing to be gained from his love.

Sometimes love must also be grabbed, even it must break the rules. Even it has already owned by other. The story came from Jack and Rose, from Titanic. This movie became a romantic movie along nineties era. But, this story described the love could be grabbed for a few days. Jack was a poor man he got the ship ticket of winning the lottery with his friend. 
In the middle of his trip, he saw a beautiful woman on the car, that she took the ship. Unfortunately, the woma had a fiance that wanted to get marry. A brave Jack, tried to close her. An accident happened in a night, when Rose wanted to end her life. She thought that her mother urged her to marry her fiance, her love was urged tightly. She ran and wanted to jump from a huge ship, Titanic into the cold sea. Jack saw her, and he tried to help. he persued her to remit her aim to suicide. Until, she almost fell into the sea, Jack helped her successfully.

Then, they began to close each other, without knowing of her fiance, and that was the beginning of restricted of forbidden love. Jack pretended to be a rich man. He was helped by an old woman, she made him being fahionable like a pride patrician. On the other hand, Jack was an artistic painter. He could paint any objects. He showed his works to Rose, he hoped that someday she wanted be to painted by him. The day was coming, Rose asked him to paint her body nudely with a deep blue sea ruby on her neck. The story was not finish. Her fiance was angry to this betrayal. He asked for Jack, and wanted to kill him. But, the tragic tragedy happened. A huge Titanic began to sink, it crashed the ice berg. The side of ship was torn, the sea water flooded it. The passengers were panic, until the ship sank totally. Half of them were safe, Jack tried to save Rose. He asked her to survive on a apical of board. For the unconditional situation, Jack gave up of that, and let Rose to survive after all. So, the restricted love ended tragically.

Talking about love that grabbed from other. It happened to Sophia, a wife of Cornelis Sandvoort. In this film, it begun from naration of Maria, the maid of Cornelis Sandvoort. She told that on that land, namely Holland, there was a flower came from the east. The people of land to compete find any variants of that flower. Tulip, it had various types, but the people was curious to a variant of tulip, it was "breaker". Beside that, there was an orphan woman namely, Sophia. She had already lived for years in St. Ursula orphan house. One day, principle of nun asked her to accept an old man's proposal to be his wife. That old man was Cornelis Sandvoort. The man who had name on that land. He had reason to marry Sophia. He wanted her to bear children from his ospring, and extended his name and business.

He tried to make love with Sophia, he hoped she was going to be pregnant. He tried it everyday. He asked God before making it. Day by day he made love, but it was still not proving. He began to worry, he asked himself, whether he was still could make it or not, so he told it to Sophia. On regard this problem, Sophia went to a doctor. She wanted to know the core of her husband. The doctor that she met was obscene. He was desired to help Sophia with bad way. Then, she left him early.
To entertain himself and his wife. He decided to ask a painter to paint him and her wife. So, a painter came to his house, he was Jan Van Loos. He was passion to his profession. But, when he saw Sophia, something appeared from his heart. On that situation, Sophia was being nervous. But Van Loos tried to be calm.

One day, Sophia asked her husband, Cornelis Sandvoort to cancel the painting, she felt uncomfortable to the painter, Jan Van Loos. But, her husband told her to be calm, and let Van Loos to finish his painting. On the other place, Van Loos tried to finish it, but the face of Sophia was flirting his mind always. He ran to Sophia's house, but he did not get her. Then he sent a letter to Sandvoort to borrow his Tulip. He asked Sophia to send the Tulip to Van Loos' place. So, the restricted love begun from that place, Van Loos take her to make love, and the relationship was running smoothly.

This restricted love evoked the lies among her people. Her maid's man thought that his woman betrayed the promise, but actually it was Sophia that clothed her maid's mantle. He was upset and angry to all people in the Tulip market. But, the maid, Maria knew what her mistress did. She promised to tell Sandvoort about this case, while she was pregnant because her man. To make her calm, Sophia made a drama, as if he was pregnant. So, Maria followed what Sophia's want. This was opportunity to her to lie her husband.

During Tulip was becoming a star flower on that land. It flirted Van Loos to find a unique Tulip. He went to St. Ursula. Sophia told that there was a "breaker". On that place, Van Loos trapped by the nun, but he was not jailed by her. He asked to the nun to tell him how to expand Tulip business. He would do for his beloved woman, but the nun was still that the woman was Sophia, the wife mistress of Cornelis Sandvoort.

Here are the questions of this reseach:

1. Why does Van Loos motivate to make and defend restrictively love to Sophia in Tulip Fever film?

2. What is message that obtained from this film?

\section{RESEARCH METHODOLOGY}

This research is recently done, but here the writer tries to find something uniquely in this movie, and refferring to some resources:

\subsection{Defenition of Character}

All stories must have certain characteristics or elements. Without these elements, any piece of literature would cease to make sense or serve a purpose. For example, stories must have a plot, or 
events that take place. Another essential story element is the character. Character can be defined as any person, animal, or figure represented in a literary work. There are many types of characters that exist in literature, each with its own development and function.

Character development refers to how developed and complex a character is. Some characters start out as highly developed. For example, if we know something about how a character walks and talks, what she thinks, who she associates with, and what kind of secrets she has, she is naturally more complex and developed. Other characters develop over the course of a story, starting out one way and ending up different, becoming changed by what happens to them. Or you might only see one side of the character for a while but at some point, another side is revealed, proving the character to be more complex. The general purpose of characters is to extend the plot. Many stories employ multiple types of characters. Every story must have main characters. These are the characters that will have the greatest effect on the plot or are the most affected by what happens in the story. There are many ways to categorize main characters: protagonist or antagonist, dynamic or static character, and round or flat characters. A character can also often fit into more than one category or move through categories.

\subsubsection{Types of Character a. Major Characters}

These are the most important characters in the story. There are two types, of which there may be a couple for each.

1. Protagonist - This is the main character, around which the whole story revolves. The decisions made by this character will be affected by a conflict from within, or externally through another character, nature, technology, society, or the fates/God.

2. Antagonist - This character, or group of characters, causes the conflict for the protagonist. However, the antagonist could be the protagonist, who is torn by a problem within. Most times, something external is causing the problem. A group of people causing the conflict would be considered society, perhaps the members of a team, community, or institution. Additionally, the antagonist could be a part of nature, such as an animal, the weather, a mountain or lake. A different kind of antagonist would be an item such as a pen, car, phone, carpet, etc. These are all considered technology, since they are instruments or tools to complete a job. Finally, if the conflict comes from something out of the character's control, the antagonist is fate or God.

\section{a. Minor Characters}

These are the other characters in a story. They are not as important as the major characters, but still play a large part in the story. Their actions help drive the story forward. They may impact the decisions the protagonist or antagonist make, either helping or interfering with the conflict.

Characters can have different traits. Major characters will usually be more dynamic, changing and growing through the story while minor characters may be more static.

1. Foil - A foil is a character that has opposite character traits from another, meant to help highlight or bring out another's positive or negative side. Many times, the antagonist is the foil for the protagonist.

2. Static-Characters who are static do not change throughout the story. Their use may simply be to create or relieve tension, or they were not meant to change. A major character can remain static through the whole story.

3. Dynamic - Dynamic characters change throughout the story. They may learn a lesson, become bad, or change in complex ways.

4. Flat - A flat character has one or two main traits, usually only all positive or negative. They are the opposite of a round character. The flaw or strength has its use in the story.

5. Round - These are the opposite of the flat character. These characters have many different traits, good and bad, making them more interesting.

6. Stock - These are the stereotypical characters, such as the boy genius, ambitious career person, faithful sidekick, mad scientist, etc.

Characters are what make stories. Without a character, there is no story to tell, only a lot of scenery. Many characters in literature, television series, and movies have a huge impact on people. Some people like to live their lives through these characters, who appear to have more exciting lives. Also, these characters may seem so real and inspirational, that people forget they are fictional.

Characters become so important to the audience, that cities across the country hold conventions in which people pay a lot of money to dress and act as their favorite characters from multiple types of shows, particularly of the comic magazine genre (type of literature).

Characters are the whole reason for any story. They can be used to help teach a lesson, to entertain, to educate, and even to persuade, depending on the author's goal for the story line. Characters can be based on real people and events, or be totally unrealistic, such as space aliens. People become attached to characters as if they are real, may 
develop favorites, and relate to those that have faced similar situations.

\subsection{Definition of Motivation}

A motive is an impulse that causes a person to act. Motivation is an internal process that makes a person move toward a goal. Motivation, like intelligence, can't be directly observed. Instead, motivation can only be inferred by noting a person's behavior. Researchers have proposed theories that try to explain human motivation. These theories include drive reduction theories and Maslow's hierarchy of needs theory.

Drive reduction theories of motivation suggest that people act in order to reduce needs and maintain a constant physiological state. For example, people eat in order to reduce their need for food. The idea of homeostasis is central to drive reduction theories.Homeostasis is the maintenance of a state of physiological equilibrium.

Drive reduction theories fail to explain several aspects of motivation:

1. People sometimes aren't motivated by internal needs.

Example: Some people fast for long periods for political causes, despite feeling extreme hunger.

2. Sometimes, people continue being motivated even when they have satisfied internal needs. Example: People sometimes eat even when they don't feel hungry.

3. People are often motivated by external incentives as well as internal needs.

Example: If a person is hungry, he or she may choose to eat a salad rather than a cheeseburger because he or she wants to be slimmer.

\subsubsection{Intrinsic and Extrinsic Motivation}

A motivation may be intrinsic, extrinsic, or both:

a. Intrinsic motivation is the motivation to act for the sake of the activity alone. For example, people have intrinsic motivation to write poetry if they do it simply because they enjoy it.

b. Extrinsic motivation, on the other hand, is the motivation to act for external rewards. For example, people have extrinsic motivation to write if they do so in the hopes of getting published, being famous, or making money.

Most motivation theorists assume that motivation is involved in the performance of all learned responses; that is, a learned behavior will not occur unless it is energized. The major question among psychologists, in general, is whether motivation is a primary or secondary influence on behavior. That is, are changes in behavior better explained by principles of environmental/ecological influences, perception, memory, cognitive development, emotion, explanatory style, or personality or are concepts unique to motivation more pertinent.
For example, it is known that people respond to increasingly complex or novel events (or stimuli) in the environment up to a point and then the rate of responding decreases. This inverted-U-shaped curve of behavior is well-known and widely acknowledged (e.g., Yerkes \& Dodson, 1908). However, the major issue is one of explaining this phenomenon. Is this a conditioning (is the individual behaving because of past classical or operant conditioning), another type of external motivation such as social or ecological, an internal motivational process (e.g., cognition, emotion, or self-regulation), or is there some better explanation?

Emotion (an indefinite subjective sensation experienced as a state of arousal) is different from motivation in that there is not necessarily a goal orientation affiliated with it (Huitt, 2003a). Emotions occur as a result of an interaction between perception of environmental stimuli, neural/hormonal responses to these perceptions (often labeled feelings), and subjective cognitive labeling of these feelings (Kleinginna and Kleinginna, 1981b). Evidence suggests there is a small core of core emotions (perhaps 6 or 8) that are uniquely associated with a specific facial expression (Izard, 1990).

This implies that there are a small number of unique biological responses that are genetically hard-wired to specific facial expressions. A further implication is that the process works in reverse: if you are motivated to change how you feel and your feeling is associated with a specific facial expression, you can change that feeling by purposively changing your facial expression. As most people would rather feel happy than otherwise, the most appropriate facial expression would be a smile.

In general, explanations regarding the source(s) of motivation can be categorized as either extrinsic (outside the person) or intrinsic (internal to the person). Intrinsic sources and corresponding theories can be further subcategorized as either body/physical, mind/mental (i.e., cognitive/thinking, affective/emotional, conative/volitional) or transpersonal/spiritual.

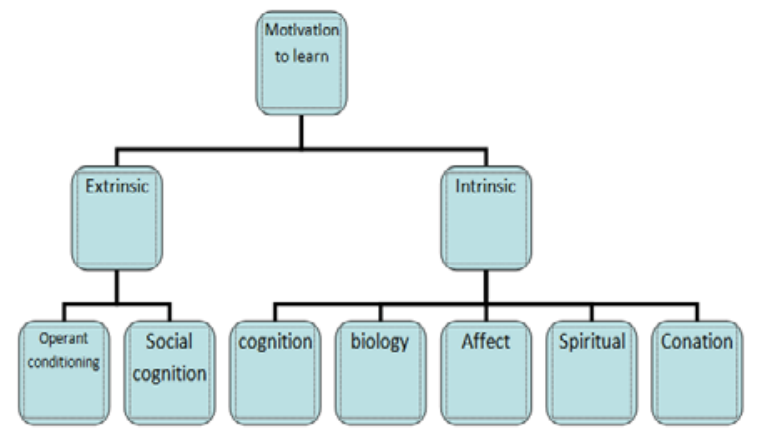

Figure 1. Diagam of Motivation 
In current literature, needs are now viewed as dispositions toward action (i.e., they create a condition that is predisposed towards taking action or making a change and moving in a certain direction; Franken, 2006). Action or overt behavior may be initiated by either positive or negative incentives or a combination of both. The following chart provides a brief overview of the different sources of motivation (internal state) that have been studied. While initiation of action can be traced to each of these domains, it appears likely that initiation of behavior may be more related to emotions and/or the affective area (optimism vs. pessimism; self- esteem; etc.) while persistence may be more related to conation (volition) or goalorientation.

\subsection{Definition of Love}

Love is a complex set of emotions, behaviors, and beliefs associated with strong feelings of affection, protectiveness, warmth, and respect for another person. Love can also be used to apply to nonhuman animals, to principles, and to religious beliefs. For example, a person might say he or she loves his or her dog, loves freedom, or loves God.

Love has been a favored topic of philosophers, poets, writers, and scientists for generations, and different people and groups have often fought about its definition. While most people agree that love implies strong feelings of affection, there are many disagreements about its precise meaning, and one person's "I love you” might mean something quite different than another's.

Some possible definitions of love include:

a. A willingness to prioritize another's well-being or happiness above your own.

b. Extreme feelings of attachment, affection, and need.

c. Dramatic, sudden feelings of attraction and respect.

d. A fleeting emotion of care, affection, and like.

e. A choice to commit to helping, respecting, and caring for another, such as in marriage or when having a child.

f. Some combination of the above emotions.

There has been much debate about whether love is a choice, is something that is permanent or fleeting, and whether the love between family members and spouses is biologically programmed or culturally indoctrinated. Love may vary from person to person and culture to culture. Each of the debates about love may be accurate in some time and some place. For example, in some instances, love may be a choice while in others it may feel uncontrollable.
Especially in the early stages of a relationship, it can be difficult to tell the difference between love and lust. Both are associated with physical attraction and an intoxicating rush of feel-good chemicals, coupled with an often overwhelming desire to be closer to another person, but only one is long-lasting: love.

Love is something that is cultivated between two people and grows over time, through getting to know him or her and experiencing life's many ups and downs together. It involves commitment, time, mutual trust, and acceptance.Lust, on the other hand, has to do with the sex-driven sensations that draw people toward one another initially and is fueled primarily by the urge to procreate. Characterized by sex hormones and idealistic infatuation, lust blurs our ability to see a person for who he or she truly is and consequently, it may or may not lead to a longterm relationship.

Although almost no one can agree on a single definition of love, most people do agree that love plays a significant role in both physical and psychological well-being. Numerous studies have demonstrated the benefits of love. Love's role in mental health is far-reaching, but some examples include:

1. The fact that babies who are not shown love and affection in the form of frequent holding and cuddling may be developmentally delayed or ill.

2. Feeling unloved is strongly correlated with feelings of low self-esteem and depression.

3. People who both feel loved by others and who report loving other people tend to be happier.

4. Love can play a role in long-term health, and feeling emotionally connected may help increase immunity.

Then, Robert Sternberg, told that the theory gets its name from the identification of three components of love: intimacy (warmth, closeness, bonding), passion (sexual desire), and commitment (deciding to stay through good time and bad). There are four varying combinations of these three components that define different types of romantic relationships. There is infatuation, which is passion with no intimacy or commitment. Romantic love has intimacy and passion but no commitment. An empty love has commitment but no intimacy or passion. The final combination is consummate love which is where all three factors are present.

\section{RESULT AND DISCUSSION}

In this research, the writer uses a qualitative desciptive method. The object of this research is Justin Chadwick's Tulip Fever film. Beside that, the 
writer also finds other sources to support this research, such as library research and surfing on the internet.

\subsection{Motivation of Van Loos to make and defend restrictively love to Sophia}

In this section, the writer is going to discuss Van Loos' motivation to make and defend his restrictively love to Sophia. The discussion taken scene by scene from Tulip Fever by Justin Chadwick. The scene wil be presented by pictures based on the plot of story.

\subsubsection{Motivation to make restrictively love to Sophia}

First, the case happened when Van Loos saw Sophia, the wife of Cornelis Sandvoort, at the first time in Sandvoort's house. As proven on the scene below:

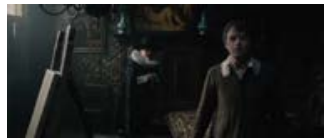

ST. 15.52

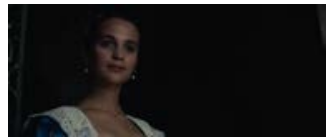

ST. 15.58
Figure 2.Van Loos's first sight

In these scenes proven that Sophia's sight drives Van Loos in to fall in love at the first sight. Van Loos could not stir his sight to Sophia, even it is impossible to own her heart. The real man, surely has a sudden feeling, when he meet a pretty girl. Bu, it must be realized that no every single woman could be owned.

On the next scene, when Van Loos paints Sophia's face. Her image disturbs his mind. His heart triggers to tell something, as shown on the scene below:

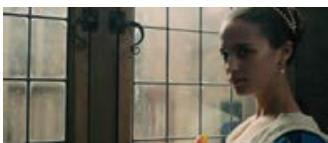

ST. 26.31

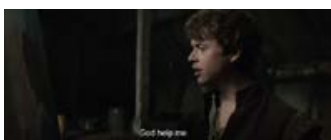

ST. 27.18
Figure 3. Sophia's face image

Van Loos is patient to paint Sophia's portrait, but her image could not go from his mind, it is must be told, even it is impossible. But it is must, on the other scene he runs to Sophia's house to tell the truth, but she is not there.

The feeling of a man, could not be guessed. It comes suddenly. The image of woman who is loved will always disturbs the mind. It is far from the sight, but it is close in the heart. That is why a man seek for a good time to tell it to the woman.

On another scene, the oppurtunnity becomes the reason for Van Loos to make restricted love to
Sophia. She also responses Van Loos's love. As taken on the scene below:

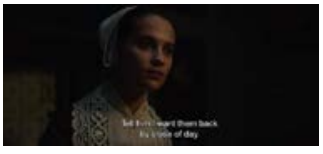

ST.30.06

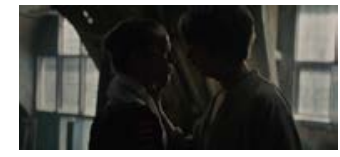

ST.31.12
Figure 4. Sophia's opportunity

After responding Van Loos' letter to Mr. Sandvoort about borrowing Tulip. He asked Sophia to take the Tulip to Van Loos' place. This scene is completing by making love done by Sophia and Van Loos. They believe, this love will be extended forever, as long as they love each other. This is the beginning of their promiscuity that could not describet by anything.

\subsubsection{Defending restrictively love to Sophia}

During Tulip fever in the land, it makes Van Loos is interesting to have business, and met the nun of St. Ursula. As proven below:

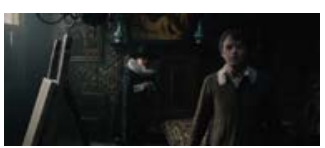

ST. 15.52

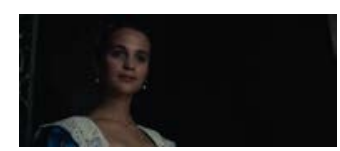

ST. 15.58
Figure 5. Van Loos's first sight

In these scenes proven that Sophia's sight drives Van Loos in to fall in love at the first sight. Van Loos could not stir his sight to Sophia, even it is impossible to own her heart. The real man, surely has a sudden feeling, when he meet a pretty girl. Bu, it must be realized that no every single woman could be owned.

\subsection{Messages obtained from Tulip Fever Film}

Promiscuity

- $\quad$ Tatapan dalam cikal bakal perselingkuhan (promiscuity)

Deceitfulness Guilt

- $\quad$ Rekaan merasa jadi bersalah (guilt)

Greediness

- Keserakahan membawa kerugian (greediness)

Forgiven past

- $\quad$ Masa lalu yang termaafkan (forgiven past)

\section{CONCLUSION}

Film is one of pop cultures. It represents the mirror of life sometimes. Recently, most of films taken from popular novels. The directors are desired to present reading print to be visioned. It makes easier 
the readers and watchers to know inside the story. So, they directly undersatnd the core of story.

The film by Justin Chadwick, Tulip Fever is representing the life in Holland few centuries ago. But, there is a restricted love between a painter, Jan Van Loos and mistress of a pride patrician, Sophia the wife of Cornelis Sandvoort. It reveals the motiva ion of painter to make and defend his restricted love to Sophia.

During Tulip was becoming a star flower on that land. It flirted Van Loos to find a unique Tulip. He went to St. Ursula. Sophia told that there was a "breaker". On that place, Van Loos trapped by the nun, but he was not jailed by her. He asked to the nun to tell him how to expand Tulip business. He would do for his beloved woman, but the nun was still that the woman was Sophia, the wife mistress of Cornelis Sandvoort.

\section{REFERENCES}

J. Jucius, Michael. 1975. Personnel Management. Virginia: R. D. Irwin
Nevid, JS. 2013. Psychology: Concepts and Applications. Belmont, CA:

Wadsworth Cengage Learning Prinz, J. J. 2007. The Emotional

Construction of Morals. Oxford: Oxford University Press

Wilson, G. D. \& McLaughlin, C. 2001. The Science of Love. London: Fusion Press

Uno, H. B. (2006). Teori Motivasi dan Pengukurannya. Jakarta : Bumi Aksara.

Azwar, S. (1995). Sikap Manusia : Teori dan Pengukurannya. (Edisi ke-2). Yogyakarta : Pustaka Belajar.

Fromm, Erich. 2005. The Art Of Loving. Jakarta : Gramedia Pustaka Utama

Hauck, Paul. 1993. Bagaimana Mencintai dan Agar dicintai. Jakarta : Arcan.

Widianti, Dian. 2006. Ensiklopedi Cinta. Bandung : Mizan Media Utama (MMU) 